\title{
Keadilan Restoratif Sebagai Paradigma Pemidanaan Di Indonesia
}

\author{
Brilian Capera \\ Magister Hukum Fakultas Hukum Universitas Islam Indonesia Yogyakarta Indonesia \\ Jln. Cik Di Tiro No. 1 Yogyakarta Indonesia \\ 19912046@students.uii.ac.id
}

\begin{abstract}
This study aims to examine restorative justice as a paradigm of punishment in Indonesia. This is a normative legal research that uses statutory and conceptual approaches. The results of this study indicate that the criminal system in force in Indonesia is still based on the repressive paradigm of retributive justice, so that imprisonment is the most frequent punishment imposed on perpetrators of criminal acts. To be able to achieve the expected sentencing objectives, namely to fulfill the rights of the parties, it is important to build a paradigm of punishment based on restorative justice through changes in legal substance, legal structure, and legal culture so that the effectiveness of criminal law enforcement can be realized.
\end{abstract}

Key Words: Paradigm; penal system; restorative justice

\begin{abstract}
Abstrak
Penelitian ini bertujuan untuk mengetahui kajian atas keadilan restoratif sebagai paradigma pemidanaan di Indonesia. Penelitian ini merupakan penelitian hukum normatif yang menggunakan pendekatan perundang-undangan dan pendekatan konseptual. Hasil penelitian ini menyimpulkan bahwa sistem pemidanaan yang berlaku di Indonesia masih berdasar pada paradigma keadilan retributif yang sifatnya represif, sehingga pidana penjara menjadi pidana yang paling sering dikenakan kepada pelaku perbuatan pidana. Untuk dapat mencapai tujuan pemidanaan yang diharapkan yaitu memenuhi hak-hak para pihak, penting untuk membangun paradigma pemidanaan berbasis keadilan keadilan restoratif melalui perubahan substansi hukum, struktur hukum, dan budaya hukum sehingga dapat terwujud efektivitas penegakkan hukum pidana.
\end{abstract}

Kata-kata Kunci: Keadilan restoratif; paradigma; sistem pemidanaan 


\section{Pendahuluan}

Secara teoritis, perkara pidana dapat ditutup demi hukum dan dihentikan penuntutannya berdasarkan keadilan restoratif dalam hal terpenuhi beberapa syarat, yaitu pertama, tersangka baru pertama kali melakukan tindak pidana, kedua, tindak pidana hanya diancam dengan pidana denda atau diancam dengan pidana penjara tidak lebih dari 5 tahun, dan ketiga, tindak pidana dilakukan dengan nilai barang bukti atau kerugian yang ditimbulkan akibat dari tindak pidana tidak lebih dari Rp. 2.500.000,00.1 Pada prakteknya, perkara pidana yang seharusnya diselesaikan dengan restoratif masih diperiksa di pengadilan sedangkan perkara tersebut dapat dihentikan atau diselesaikan di tahap penyidikan di kepolisian atau di tahap penuntutan di kejaksaan. Hal ini dibuktikan dengan adanya data jumlah perkara yang diperiksa dengan acara cepat pada 2021 di Kota Yogyakarta adalah 40 perkara, pada 2019 hingga 2021di Kabupaten Bantul terdapat 149 perkara, dan 214 perkara pada 2019 hingga 2021 di Kabupaten Sleman. ${ }^{2}$ Akibatnya, beban pengadilan bertambah serta menambah beban LAPAS yang menampung warga binaan.

Perbuatan pidana menurut Moeljatno adalah perbuatan yang merugikan masyarakat, dalam arti bertentangan dengan atau menghambat akan terlaksananya tata dalam pergaulan masyarakat yang baik dan adil, serta anti sosial. ${ }^{3}$ Sebagai hukum publik, hukum pidana mengatur sanksi bagi pelaku perbuatan pidana sebagai hukuman atas dirugikannya kepentingan masyarakat. Salah satu sanksi pidana tersebut yaitu pidana penjara. Penjara dalam konsep keadilan retributif merupakan bentuk kesengsaraan bagi pelaku yang merupakan balasan bagi pelaku dan tujuan dari hukum pidana itu sendiri. Pidana adalah hukuman berupa siksaan atau penderitaan yang merupakan keistimewaan dan unsur yang terpenting dalam hukum pidana. ${ }^{4}$

Pada perkembangannya, beberapa kajian mengenai efektivitas pemidanaan berpendapat bahwa hukuman penjara bukan pilihan yang tepat karena hukum pidana diciptakan untuk membuat masyarakat menjadi sadar, taat, patuh, sehingga menjadikan manusia tidak melanggar hukum yang keduakalinya. Selain itu, hukum pidana dapat memulihkan kerugian yang timbul akibat perbuatan pelaku. Hukum bukan mengurung orang dipenjara yang belum tentu memulihkan keadaan seperti sediakala. Oleh karena itu, pidana penjara bukan

\footnotetext{
${ }^{1}$ Pasal 5 ayat (1) Peraturan Kejaksaan No. 15 Tahun 2020 tentang Penghentian Penuntutan Berdasarkan Keadilan Restoratif.

2 Hasil pengolahan data yang diperoleh peneliti melalui observasi langsung pada pengadilan yang berkaitan langsung dengan penelitian

${ }^{3}$ Moeljatno, Asas-Asas Hukum Pidana, Rineka Cipta, Jakarta, 2008, hlm. 3.

${ }^{4}$ Kansil, Pengantar Ilmu Hukum dan Tata Hukum Indonesia, Balai Pustaka, Jakarta, 1989, hlm. 259.
} 
hukuman yang selalu tepat. Hukum yang tepat adalah hukum yang keberlakuannya tidak menimbulkan pertentangan dan bukan menjadikan masyarakat takut hukum. Ketertiban di masyarakat bukan karena hukumannya, tetapi karena ada norma-noma dan nilai yang ingin dilindungi oleh hukum itu.

Pemenjaraan tidak banyak menghasilkan output yang diharapkan yaitu bahwa jika seseorang yang telah menjalani pidana, dirinya akan menjadi orang yang lebih baik. Fenomena ini disebut dengan siklus kriminal, yaitu penjara tidak dapat untuk menjadikan narapidana menjadi warga negara yang baik, bahkan di beberapa kasus, mereka malah menjadi semakin ahli dalam melakukan tindak kejahatan. ${ }^{5}$ Penjara seharusnya bertujuan cara agar pelaku jera karena perbuatan dan sebagai pencegahan seseorang melakukan perbuatan yang dilarang. Prisonisasi terhadap warga binaan sulit untuk dihindari, terlebih jika pengawasan oleh petugas tidak dilakukan secara optimal. ${ }^{6}$

Hukum pidana dikatakan sudah berjalan sebagaimana tujuan dan fungsi hukum pidana apabila penjatuhan penjara akan membawa seseorang menjadi lebih baik setelah keluar dari penjara. Sebaliknya, jika seseorang yang keluar penjara tidak menjadi pribadi yang lebih baik maka hukum tidak berjalan sebagaimana fungsi dan tujuan hukum di masyarakat. Oleh karena itu, tidak dapat menilai efektivitas atau berhasilnya hukum pidana dilihat dari adanya berapa jumlah penjara dan seberapa banyak orang yang masuk penjara, tetapi bagaimana sistem pidana itu dapat membentuk pribadi pelaku menjadi baik dan bukan anti sosial sebagaimana pendapat dari Moeljatno di atas. Dengan kata lain, pidana penjara atau pidana apapun bentuknya menjadi cara membentuk pribadi pelaku menjadi manusia yang baik seutuhnya. Seseorang yang keluar dari penjara diharapkan tidak mengulangi perbuatan jahatnya serta dapat bermanfaat bagi bengsa dan negara, oleh karena itu penjara disebut juga Lembaga Pemasyarakatan. Selain itu, pemidanaan membuat manusia tidak melakukan halhal yang dilarang oleh hukum atau bertentangan dengan moral masyarakat.

Pidana penjara sebagai salah satu pidana pokok yang diatur dalam Pasal 10 KUHP masih menjadi prioritas dalam menghukum pelaku kejahatan di Indonesia. Ancaman pidana penjara yang bersifat imperatif di Indonesia tersebut merupakan warisan dari pemikiran aliran klasik yang menetapkan pidana dengan definite sentence atau mengandung perintah tertulis dalam UU.7 Hukum pidana dalam kerangka aliran klasik disebut daadstrafrecht atau tatsstrafrecht yaitu

${ }^{5}$ Pajar Hatma Indra Jaya, "Efektifitas Penjara Dalam Menyelesaikan Masalah Sosial”, Hisbah, Vol. 9 No. 1. t.b, 2012, hlm. 2.

6 I Wayan Putu Sucana Aryana, "Efektivitas Pidana Penjara Dalam Membina Narapidana”, Jurnal Ilmu Hukum, Vol.11 No. 21, Februari 2015, hlm. 41.

${ }^{7}$ Ibid., 39. 
hukum pidana yang berorientasi pada perbuatan (offense oriented). ${ }^{8}$ Hukum positif harus dipahami sebagai peraturan tertulis, penguasa memiliki kekuasaan dalam menetapkan hukum materill.

Pengaruh aliran klasik tersebut termuat dalam ketentuan asas legalitas yang berarti bahwa negara berkewajiban untuk menjelaskan perbuatan mana saja yang dapat dipidana. ${ }^{9}$ Pidana penjara sebagai salah satu cara untuk membatasi perilaku menyimpang dan sebagai pembalasan perbuatan pelaku yang melanggar kebebasan moral. Oleh karena itu, penelitian ini akan mengkaji bagaimana pentingnya mengubah paradigma atau wawasan berpikir terhadap pemidanaan yang berfokus pada pembalasan kepada pemulihan sehingga memberikan manfaat dan tujuan yang efektif dalam rangka membina pelaku menjadi manusia yang baik.

\section{Rumusan Masalah}

Berdasarkan latar belakang masalah di atas, rumusan masalah penelitian ini adalah bagaimana kajian atas keadilan restoratif sebagai paradigma pemidanaan di Indonesia?

\section{Tujuan Penelitian}

Tujuan penelitian ini adalah untuk mengetahui kajian atas keadilan restoratif sebagai paradigma pemidanaan di Indonesia.

\section{Metode Penelitian}

Penelitian ini merupakan jenis penelitian hukum normatif, yaitu penelitian yang dilakukan untuk menemukan peraturan hukum, prinsip hukum maupun doktrin hukum guna menjawab isu hukum yang dihadapi sehingga diperoleh argumentasi, teori atau konsep. Metode pendekatan yang digunakan adalah pendekatan perundang-undangan dan pendekatan konseptual. Sumber data penelitian berupa data sekunder yang terdiri atas bahan hukum primer, bahan hukum sekunder, dan bahan hukum tersier. Data tersebut dianalisis menggunakan metode deskriptif kualitatif yaitu memaparkan secara rinci peristiwa hukum yang menjadi objek penelitian serta dianalisis dengan teori, konsep atau prinsip hukum serta hukum positif dengan menggunakan kata-kata yang mudah dipahami secara ilmiah.

8 Syaiful Bakhri, "Pengaruh Aliran-Aliran Falsafat Pemidanaan dalam Pembentukan Hukum Pidana Nasional", Jurnal Hukum, Vol. 18 No. 1, Januari 2010, hlm. 146.

${ }^{9}$ Ibid., hlm. 143-144. 


\section{Hasil Penelitian dan Pembahasan}

Hukum pidana mengatur bagaimana bentuk perbuatan yang dilarang dan bentuk hukumannya serta mengatur siapa yang dapat dipidana. Hukum pidana merupakan hukum publik sebagai perlindungan negara terhadap warga negara karena ada pelanggaran terhadap kepentingan umum. Adapun yang termasuk dalam pengertian kepentingan umum ialah badan dan peraturan perundangan negara dan kepentingan hukum tiap manusia. ${ }^{10}$ Pelanggaran atas kepentingan publik tersebut memaksa negara dengan alat kelengkapan mengatasi pelaku dengan hukum pidana. Dalam rangka melindungi dan menciptakan ketentraman serta melindungi dari "pemerkosaan" atau pelanggaran terhadap berbagai kepentingan hukum, maka negara diberikan wewenang dan kekuasaan untuk menjatuhkan pidana, tindakan atau kebijaksanaan sesuai peraturan yang berlaku. ${ }^{11}$

Untuk dapat dipatuhinya norma hukum tersebut maka dalam hukum pidana mengatur sanksi yang dapat dikenakan terhadap siapa yang melanggar norma tersebut. Hukum pidana dalam KUHP telah mengatur yaitu sebagaimana Pasal 10 KUHP terdiri atas pidana pokok dan pidana tambahan. Pidana pokok tersebut yaitu pidana mati, penjara, kurungan, dan denda, sedangkan pidana tambahan terdiri atas pencabutan hak-hak tertentu, perampasan barang-barang tertentu, dan pengumuman keputusan hakim. Pemidanaan dan sistem pidana memiliki arti penting dalam hukum pidana serta dipengaruhi oleh sistem sosial masyarakat. Menurut Sholehudin, sanksi merupakan hal yang penting dalam hukum pidana karena dapat mencerminkan nilai-nilai sosial budaya suatu masyarakat. ${ }^{12}$

Barda Nawawi Arief mendefinisikan pemidanaan secara luas sebagai suatu proses pemberian atau penjatuhan pidana oleh hakim sehingga sistem pemidanaan mencakup keseluruhan ketentuan perundang-undangan yang mengatur bagaimana hukum pidana itu ditegakkan atau dioperasionalkan secara konkret sehingga seseorang dijatuhi sanksi (hukum pidana). ${ }^{13}$ Pengertian pemidanaan menurut Andi Hamzah adalah suatu pengertian umum, sebagai suatu sanksi yang menderitakan atau nestapa yang sengaja ditimpakan kepada

\footnotetext{
${ }^{10}$ Kansil, Op, Cit., hlm. 257

11 Failin, "Sistem Pidana Dan Pemidanaan Di Dalam Pembaharuan Hukum Pidana Indonesia", Jurnal Cendekia Hukum, Vol. 3 No. 1, September 2017, hlm. 15.

${ }^{12}$ Failin, Op. Cit., hlm. 19.

13 Barda Nawawi Arief, Bunga Rampai Kebijakan Hukum Pidana, Citra Aditya Bakti, Bandung, 2002, hlm. 129 dikutip dari http:/ /e-journal.uajy.ac.id/18184/3/HK118182.pdf
} 
seseorang sedangkan pidana merupakan suatu pengertian khusus yang berkaitan dengan hukum pidana. ${ }^{14}$

Realitas yang ada di Indonesia, kejahatan seperti pencurian, pembunuhan, pemerkosaan, penipuan, penadahan dll masih menggunakan pendekatan pembalasan pada pelaku kejahatan yang dianggap merusak ketertiban. Pelaku yang tertangkap diperiksa oleh penyidik dan menjalani persidangan dan kemungkinan besar proses penyelesaian atau output yang dihasilkan adalah orang tersebut akan masuk penjara atau bebas. Terkait hal ini, sistem database pemasyarakatan 5 Agustus 2018 menunjukkan bahwa jumlah tahanan dan warga binaan di seluruh Lembaga Pemasyarakatan (Lapas) dan Rumah Tahanan (Rutan) di Indonesia sebanyak 250.444 orang. ${ }^{15}$ Angka tersebut sudah berlebih mengingat Lapas dan Rutan ideal hanya menampung sebanyak 124.696 orang. ${ }^{16}$

Data di atas menujukkan bahwa pidana penjara menyebabkan lembaga pemasayarakatan penuh sesak ternyata tidak membuat narapidana jera dan korban tidak mendapatkan pemulihan apa-apa dari si pelaku. Selain tidak bermanfaat bagi korban, pidana penjara berdampak destruktif bagi narapidana yaitu terdapat kecenderungan bahwa orang-orang yang telah menjalani hukuman penjara ternyata lebih sulit untuk menyesuaikan diri di masyarakat dan sekaligus memiliki kerentanan untuk mengulangi tindak pidana. ${ }^{17}$ Sistem pemidanaan yang menekankan pada pembalasan tersebut juga menimbulkan terjadinya recidive delicten mengingat pemidanaan tersebut tidak berorientasi pada pemulihan pelaku dan kepentingan korban.

Pemaparan di atas menunjukkan bahwa hukum pidana Indonesia masih menggunakan paradigma keadilan retributif yang memandang pemidanaan terhadap pelaku kejahatan merupakan cara satu-satunya dalam mencapai keadilan bagi korban dan masyarakat. Jadi, hukum pidana yang selama ini dipakai sebagai salah satu sarana untuk menangulangi kejahatan dibangun atas dasar paradigma retributif sehingga sifatnya yang represif dan koersif sangat mendominasi. ${ }^{18} \mathrm{Hal}$ ini didasarkan pada fakta bahwa hukum pidana Indonesia masih mengikuti WvS Belanda dimana WvS tersebut masih menerapkan pidana secara individual yang sudah tidak relevan lagi dengan perkembangan kejahatan saat ini. ${ }^{19}$ Oleh karena itu, untuk dapat mencapai tujuan pemidanaan yang diharapkan yaitu memneuhi

\footnotetext{
${ }_{14}$ Andi Hamzah, Sistem Pidana dan Pemidanaan Indonesia, PT. Pradnya Paramita, Jakarta, 1993, hlm. 1

15 T.n., " Restorative Justice, Solusi Over Kapasitas Lapas Rutan" https://sulsel.kemenkumham.go.id/ pusat-informasi/artikel/4443-restorativejustice-solusi-over-kapasitas-lapas-rutan diakses 13 Januari 2021, 13.13.

16 Ibid.

${ }^{17}$ Erasmus A.T. Napitupulu. dkk, Hukuman Tanpa Penjara: Pengaturan, Pelaksanaan, dan Proyeksi Alternatif Pemidanaan Non Pemenjaraan di Indonesia, ICJR, Jakarta, 2019, hlm. iii.

${ }^{18}$ G. Widiartana, "Paradigma Keadilan Restoratifdalam Penanggulangan Kejahatan dengan Menggunakan Hukum Pidana”, Justicia Et Pax, Vol.3 3No. 1, t.b, 2017, hlm. 1.

${ }^{19}$ Failin, Op. Cit., hlm. 16.
} 
hak-hak para pihak, maka paradigma yang dibangun sudah tidak menggunakan retributif, tetapi hendaknya dibgnun berdasarakan keadilan restoratif yaitu pemulihan kepada keadaan semula sebelum adanya persitiwa pidana.

Keadilan restoratif adalah penyelesaian perkara tindak pidana dengan melibatkan pelaku, korban, keluarga pelaku/korban, dan pihak lain yang terkait untuk bersama-sama mencari penyelesaian yang adil dengan menekankan pemulihan kembali pada keadaan semula, dan bukan pembalasan..$^{20}$ Keadilan restoratif merupakan suatu subsistem pemidanaan dimana dengan subsistem lain saling berhubungan dan bekerja untuk mencapai kemanfaatan. Prinsip keadilan restoratif yaitu korban mendapatkan ganti kerugian yang menderita kerugian, perdamaian serta kesepakatan yang dapat memulihkan keadaan korban. ${ }^{21}$

Mengubah paradigma keadilan retributif menuju keadilan restoratif merupakan hal yang tidak mudah dan tidak dapat dilakukan tanpa pertimbangan kondisi soial kemasyarakatan. Kajian terhadap kondisi politik, ekonomi dan sosial budaya Indonesia yang majemuk harus dipertimbangkan dalam menetapkan sistem hukum pidana. Diperlukan adanya hukum materil dan formil yang mendukung penegakan hukum yang berbasis pada keadilan restoratif sehingga sistem pemidanaannya berorientasi pada kepentingan pelaku, korban, dan masyarakat. Keadilan restoratif itu tidak dapat diartikan meniadakan pidana penjara, namun membawa kasus pada jalan di luar proses persidangan yaitu perdamaian.

Upaya mengubah paradigma pemidanaan tersebut dapat dilakukan dengan berdasar pada kajian efektivitas hukum yang dikemukakan oleh Lawrence Friedman yang terdiri atas substansi hukum, struktur hukum, dan budaya hukum. Substansi hukum, dapat mencakup asas hukum, norma hukum dan aturan hukum, baik yang tertulis maupun yang tidak tertulis. Substansi hukum pidana di Indonesia sebagai contoh Kitab Undang-Undang Hukum Pidana (KUHP) sebagai induk hukum pidana materiil, sedangkan induk hukum pidana formil adalah Kitab Undang Undang Hukum Acara Pidana (KUHAP). ${ }^{22}$ Struktur hukum merupakan apparat penegak hukum sebagai komponen struktural (institusional) berserta mekanisme prosedural atau administrasi, bentuk hukum, lembaga-lembaga hukum, perangkat hukum. ${ }^{23}$ Budaya hukum merupakan profesionalisme penegak hukum, serta kesadaran masyarakat dalam menaati

\footnotetext{
${ }^{20}$ Pasal 1 angka 1 Peraturan Kejaksaan No. 15 Tahun 2020 tentang Penghentian Penuntutan Berdasarkan Keadilan Restoratif

21 Surat Keputusan Direktur Jendral Badan Peradilan Umum No. 1691/DJU/SK/PS.00/12/2020 tentang Pedoman Penerapan Restorative Justice Di Lingkungan Peradilan Umum.

22 Anwar Anas, "Komponen Sistem Hukum Menurut Lawrence M. Friedman", https://owntalk.co.id/2020/11/23/komponen-sistem-hukum-menurut-lawrence-m-friedman/, diakses Rabu, 13 Januari 2021, pukul 16.50

${ }^{23}$ Lutfil Ansori, "Reformasi Penegakan Hukum Perspektif Hukum Progresif”, Jurnal Yuridis, Vol.4 No. 2, Desember 2017, hlm. 153.
} 
hukum itu sendiri sebab hukum itu akan efektif jika diterima oleh masyarakat. ${ }^{24}$ Budaya hukum juga dapat diartikan sebagai nilai-nilai budaya hukum yang mencakup filsafat hukum, asas-asas hukum, teori hukum, ilmu hukum, dan kesadaran atau sikap perilaku hukum. ${ }^{25}$

Ketiga faktor yang mempengaruhi efektivitas penegakkan hukum di atas dapat dijadikan dasar untuk membangun paradigma penegakan hukum, termasuk sistem pemidanaannya, yang berbasis restorative justice. Penegak hukum dapat membuat terobosan dengan mengeluarkan produk hukum sebagai upaya sosialisasi keadilan restoratif di masyarakat. Saat ini produk hukum yang mengatur keadilan restoratif masih terbatas karena keadilan restoratif masih menjadi konsep. Hal ini terlihat dari masih belum ada peraturan tegas yang menjadi pedoman dalam menerapkan keadilan restoratif dalam penegakan hukum. Selain itu, perlu adanya persamaan persepsi dalam implementasi substansi hukum yang berbasis paradigma keadilan restoratif tersebut di ranah praktis sehingga dapat memberikan pemahaman kepada masyarakat terkait paradigma tersebut. Jadi, pemidanaan harus mempertimbangkan berbagai faktor dibalik penjatuhan sanksi serta apakah pemidanaan tersebut efektif dan efisien atau tidak sehingga penting untuk mengubah paradigma pemidanaan yang saat ini berdasar pada keadilan retributif menjadi berparadigma keadilan restoratif melalui perubahan substansi hukum, struktur hukum, dan budaya hukum.

\section{Penutup}

Hukum pidana Indonesia masih menggunakan paradigma keadilan retributif yang memandang pemidanaan terhadap pelaku kejahatan merupakan cara satusatunya dalam mencapai keadilan bagi korban dan masyarakat. Sistem pemidanaan sebagai bagian dari hukum pidana merupakan suatu proses pemberian atau penjatuhan pidana oleh hakim. Artinya, sistem pemidanaan yang berlaku sekarang ini juga masih berdasar pada paradigma keadilan retributif yang sifatnya represif dan koersif dimana hal ini terbukti dari dominasi pidana penjara sebagai pidana yang paling sering dikenakan kepada pelaku perbuatan pidana. Oleh karena itu, untuk dapat mencapai tujuan pemidanaan yang diharapkan yaitu memenuhi hakhak para pihak, penting untuk mengubah paradigma pemidanaan yang saat ini berdasar pada keadilan retributif menjadi berparadigma keadilan restoratif melalui perubahan substansi hukum, struktur hukum, dan budaya hukum untuk meningkatkan efektivitas penegakan hukum pidana.

\footnotetext{
${ }^{24}$ Ibid.

${ }^{25}$ Yoyok Ucok Suyono dan Dadang Firdiyanto, Mediasi Penal Alternatif Penyelesaian Perkara dalam Hukum Pidana, Laksbang Justicia, Yogyakarta, 2020, hlm. 71
} 


\section{Daftar Pustaka}

\section{Buku}

A.T. Napitupulu, Erasmus, Dkk., Hukuman Tanpa Penjara: Pengaturan, Pelaksanaan, dan Proyeksi Alternatif Pemidanaan Non Pemenjaraan di Indonesia, ICJR, Jakarta, 2019.

Hamzah, Andi, Sistem Pidana dan Pemidanaan Indonesia, PT. Pradnya Paramita, Jakarta, 1993.

Kansil, Pengantar Ilmu Hukum dan Tata Hukum Indonesia, Balai Pustaka, Jakarta, 1989.

Moeljatno, Asas-Asas Hukum Pidana, Rineka Cipta, Jakarta, 2008.

Muhammad, Rusli, Sistem Peradilan Pidana, UII Press, Yogyakarta, 2011.

Nawawi Arief, Barda, Teori dan Kebijakan Pidana, Alumni, Bandung, 1992.

Rahardjo, Satjipto, Ilmu Hukum, Citra Aditya Bakti, Bandung, 2012.

Ucok Suyono, Yoyok, Dadang Firdiyanto, Mediasi Penal Alternatif Penyelesaian Perkara dalam Hukum Pidana, Laksbang Justicia, Yogyakarta, 2020.

\section{Jurnal/ Makalah}

Bilher Hutahaean. "Penerapan Sanksi Pidanabagi Pelaku Tindak Pidana Anak". KY. Vol. 6 No. 1. Jakarta, 2013, hlm. 68-69.

Failin, "Sistem Pidana Dan Pemidanaan Di Dalam Pembaharuan Hukum Pidana Indonesia", Jurnal Cendekia Hukum, Vol. 3 No. 1, September 2017, hlm. 15.

G. Widiartana, "Paradigma Keadilan Restoratif Dalam Penanggulangan Kejahatandengan Menggunakan Hukum Pidana", Justicia Et Pax, UAJY. Vol. 3 No. 1. Yogyakarta, 2017, hlm. 1. http:/ /e-journal.uajy.ac.id/18184/ 3/HK118182.pdf

I Wayan Putu Sucana Aryana, "Efektivitas Pidana Penjara Dalam Membina Narapidana", Jurnal Ilmu Hukum, Vol.11 No. 21, Februari 2015, hlm. 41.

Islamiyati.. "Kritik Filsafat Hukum Positivisme Sebagai Upaya Mewujudkan Hukum Yang Berkeadilan”. UMS, Vol. 1 No. 1. Surakarta, 2018, hlm. 84.

Lutfil Ansori, "Reformasi Penegakan Hukum Perspektif Hukum Progresif”, Jurnal Yuridis, UPN Veteran. Vol. 4 No. 2. Jakarta, 2017, hlm. 153.

Maryati, "Pergeseran Paradigma Hukumdari Hukum Positif Menuju Hukum Progresif". Universitas Batanghari. No. 12. Jambi, 2010, hlm. 30.

Nazaruddin Lathif.. “Teori Hukum Sebagai Sarana / Alat Untuk Memperbaharui Atau Merekayasa Masyarakat". Universitas Pakuan. Vol. 3 No. 1. Bogor, 2017, hlm. 74.

Pajar Hatma Indra Jaya, "Efektifitas Penjara Dalam Menyelesaikan Masalah Sosial", Hisbah, Vol. 9 No. 1. t.b, 2012, hlm. 2.

Rusli Muhammad. 2006. “Tinjauan Kritis Terhadap Kebijakan Pengaturan Masalah Pidana dan Pemidanaan dalam RUU KUHP". UNISSULA. Vol.13 No. 2. Semarang, 160. 
Syaiful Bakhri, "Pengaruh Aliran-Aliran Falsafat Pemidanaan dalam Pembentukan Hukum Pidana Nasional", Jurnal Hukum, Vol. 18 No. 1, Januari 2010, hlm. 146.

Syaiful Bakhri. 2010. "Pengaruh Aliran-Aliran Falsafat Pemidanaan dalam Pembentukan Hukum Pidana Nasional". UNISSULA. Vol.18 No. 1. Semarang, 143-144.

Wagiman. 2016. “Nilai, Asas, Norma, Danfaktahukum: Upaya Menjelaskan Dan Menjernihkan Pemahamannya". Universitas 17 Agustus. Vol.1 No. 1. Jakarta, 47

\section{Website}

Anwar Anas, https://owntalk.co.id/2020/11/23/komponen-sistem-hukummenurut-lawrence-m-friedman/ "Komponen Sistem Hukum Menurut Lawrence M. Friedman" (Rabu, 13 Januari 2021, 16.50)

Shidarta, https://business-law.binus.ac.id/2015/01/22/seputar-paradigmapemikiran-hukum/ "Seputar Paradigma Pemikiran Hukum" (Rabu, 13 Januari 2021, 13.25)

T.n., $\quad$ https://sulsel.kemenkumham.go.id/pusat-informasi/artikel/4443restorativejustice-solusi-over-kapasitas-lapas-rutan " Restorative Justice, Solusi Over Kapasitas Lapas Rutan" (Rabu, 13 Januari 2021, 13.13)

T.n., https://komisi-kejaksaan.go.id/degrasi-moral-penegak-hukum/ "Degadasi Moral Penegak Hukum" (Rabu, 13 Januari 2021, 17.14) 